\title{
Tracking stem cells in the incisional hernial sac: a gaze beyond pure tissue repairs
}

\section{Rastreando células-tronco no saco herniário incisional: um olhar para além dos reparos puramente teciduais}

Renato Miranda de Melo, tCBC-GO $1,2,3$ [i]; Roberpaulo Anacleto Neves ${ }^{4}$ id ; Liliana Borges de Menezes ${ }^{5}$ iD.

\author{
A B S T R A C T
}

\begin{abstract}
Objective: the hernial sac is typically a bilayer structure consisting of connective tissue lined underneath by peritoneum. Some incidental findings on it, like smooth muscle cells and heterotopic ossification, can be explained as the end-stage metaplasia from undifferentiated cells. This study aimed to search for mesenchymal stem cells in the incisional hernial sac by an immuno-histochemistry screening test. Methods: fifteen specimens of them were submitted to histochemistry analysis using CD133 monoclonal antibodies, a specific marker of mesenchymal stem cells. The biopsies were obtained from patients submitted to pure tissue repair for incisional hernias - the transposition with the hernial sac technique (Lázaro da Silva, 1971). Results: two-thirds of the specimens expressed on average 20 (twenty) CD133+ cells in each one. Conclusion: despite the screening nature of this study, the hernial sac may be considered a source of stem cells. This could explain those abnormal findings, and perhaps the induction of new fibroblasts in procedures that use it to optimize wound healing.
\end{abstract}

Keywords: Stem Cells. Peritoneum. Reconstructive Surgical Procedures. Abdominal Wall.

\section{INTRODUCTION}

$T^{\text {nen }}$ he hernial sac (HS) - the end-product of hernial disease - is a bilaminar structure consisting of connective tissue covered by mesothelial cells of the peritoneum. This histologically heterogeneous and complex membrane can be considered one of the repositories of adult stem cells in our body'. In a recent review, mesothelial cells of the visceral peritoneum induced the "peritonealization" of polypropylene meshes, increasing the formation of adhesions and, at the same time, decreasing the integration of this material to the parietal side. The authors concluded that an autologous approach would be preferable to an allogeneic implant ${ }^{2}$.

Some incidental findings in the HS, such as smooth muscle cells ${ }^{3}$ and heterotopic ossification ${ }^{4}$, can be a final stage of metaplasia from primitive cells. By a similar biological process, the "epithelial-to-mesenchymal" transition of these cells, and finally to fibroblasts, is the mechanism responsible for peritoneal fibrosis that occurs in some patients undergoing peritoneal dialysis, rendering this alternative route of renal clearance unfeasible ${ }^{5}$.

It seems logical to assume then that the HS, like other native tissues, would have large amounts of these less differentiated cells, originating from the peritoneal layer and/or the supporting stroma. Therefore, it is likely that this recruitment would also improve wound healing, triggered by the multiple fibroblastic metaplasias ${ }^{6}$ that occurred in these cells. This should happen with greater intensity in incisional hernia repairs that take full advantage of the HS, such as the hernial sac transposition (HST) technique, developed in Brazil in the early 1970s by Lazaro da Silva ${ }^{7,8}$. Since then, good results have been reported with this procedure, not just by its proponent ${ }^{9-14}$. However, how or why would this technique work so well, without the undeniable reinforcement of a mesh? There are possible anatomical, biomechanical, and biomolecular reasons to be raised. It is likely that those undifferentiated cells of the nearby tissues (including the HS itself) with the potential to become active fibroblasts are one of the

1 - Universidade Federal de Goiás, Faculdade de Medicina, Departamento de Cirurgia - Goiânia - GO - Brasil 2 - Santa Casa de Misericórdia de Goiânia, Serviço de Cirurgia Geral, Divisão de Hérnias Complexas - Goiânia - GO - Brasil 3 - Hospital Geral de Goiânia "Dr. Alberto Rassi" (HGG), Serviço de Cirurgia Geral/Hérnias Complexas - Goiânia - GO - Brasil 4 - Pontifícia Universidade Católica de Goiás (PUC Goiás), Setor de Histologia - Goiânia - GO - Brasil 5 - Universidade Federal de Goiás, Instituto de Patologia Tropical e Saúde Pública (IPTSP), Setor de Patologia Geral - Goiânia - GO - Brasil 
main arguments for such favorable results. One could say that Billroth's dream finally materialized, not as a magical prosthesis, but through more intense, and therefore more robust healing.

This study aimed to verify the possible presence of adult mesenchymal stem cells in incisional HS by an immunohistochemical screening test. It is part of a randomized clinical trial (triple blinded) still in progress, which investigates the effectiveness of the HST technique (with and without reinforcement of onlay mesh), whose main outcome is the recurrence rate in five years.

\section{METHODS}

The project was approved by the Ethics in Research Committees of the Hospital das Clinicas of the Federal University of Goias (HC/UFG/056/2011) and the Hospital Santa Casa de Misericordia de Goiania (HSCMG/015/2011). All patients signed an informed consent form before surgery, and HS biopsies were obtained. All procedures were performed in accordance with guidelines and regulations involving human beings.

We collected excess fragments from the incisional hernial sacs of 15 patients operated at the Hospital Santa Casa de Misericordia de Goiania, from January 2012 to June 2014. The specimens, about $2 \mathrm{~cm}^{2}$, were stretched on plastic plates by the connective tissue face and immersed in $10 \%$ buffered formaldehyde solution. After 24 hours, they were cut and kept in $70 \%$ alcohol until inclusion in paraffin. Sectioned at a thickness of $5 \mu \mathrm{m}$ and stretched again on silanized slides, the samples were incubated in a humid chamber overnight at $4^{\circ} \mathrm{C}$ with a primary monoclonal antibody specific for stem cells, obtained from rabbits and with human reactivity, CD133 (MyBioSource ${ }^{\circledR}$, San Diego, CA, USA). After 18 hours, they were bathed in distilled water and subjected to further incubation with a secondary antibody and peroxidase, at room temperature, with the $\mathrm{MACH}^{1}$ polymer system (Biocare Medical®, England). The development of this reaction was done with $\operatorname{DAB}$ (3,3'diaminobenzidine) for 10 minutes, and the counter-staining, with hematoxylin for 30 seconds. The analysis of the immunohistochemical markings of the cells was carried out with an interactive image analyzer system, AxionVision 3.1 (Carl Zeiss ${ }^{\circledR}$, Jena, Germany). The images were previously photomicrographed with 40X magnification under common light, and 10 different fields were analyzed in each slide for counting CD133+ cells and obtaining cell density (simple average of the number of cells per field). Two of the authors (RAN and LBM) performed all tests in duplicate, both in the histological processing steps (immunohistochemistry) and in the microscope analyzes.

\section{RESULTS}

After immunohistochemical processing of the samples, two thirds expressed CD133+ cells. Figure 1 depicts the typical appearance of these cells (stained in light brown color). Table 1 shows the number of cells per microscopic field, as well as the total and the average in each sample. To compensate for any bias in the calculation of the mean of CD133+ cells in each biopsied HS, we excluded null values ( 0 cells in cases $1,5,8,11$ and 15) and the highest ones found (58 cells in case 6). The average value in each sample was 20 CD133+ cells.

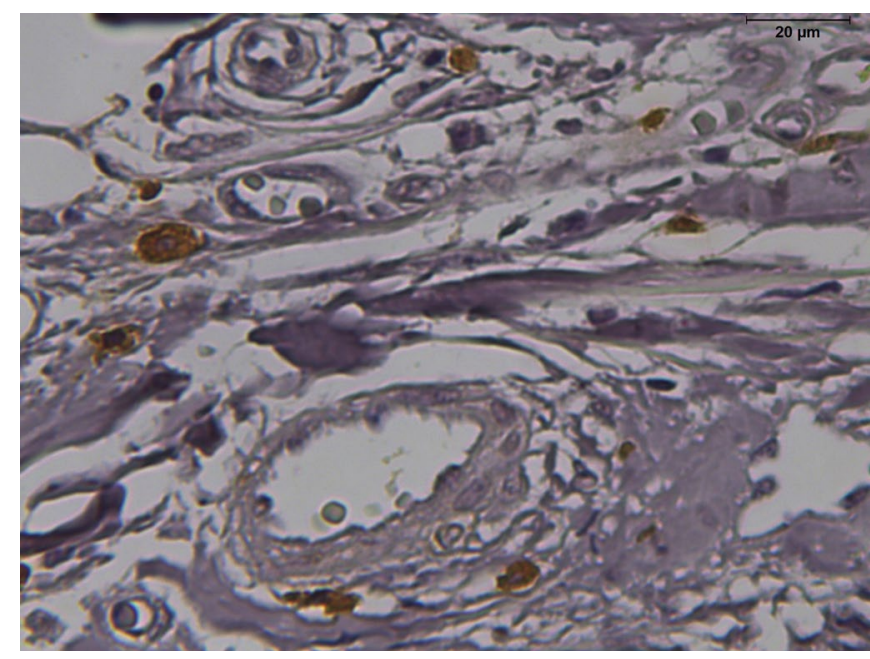

Figure 1. Photomicrograph of the human incisional HS marked with monoclonal antibody CD133 and contrasted with hematoxylin. CD133+ cells are stained in light brown, 400X.

\section{DISCUSSION}

The advent of meshes came to help surgeons and patients to deal with more severe cases of incisional hernias that progress over time, and whose recurrences persist after several attempts of surgical repair. However, the use of prostheses has not reduced the number of such reoperations, according to a population-based epidemiological study involving more than 10,000 
patients in 15 years of follow-up. Not even two major surgical innovations in the period reduced the incidence of incisional hernias: the advent of the laparoscopic approach in visceral surgery, which preserves the abdominal wall, and the routine use of meshes in hernia repair ${ }^{15,16}$.

Perhaps the largest, longest, and most complete study ever carried out on the treatment of incisional hernias was published in 2016, with 3,242 patients, $100 \%$ of whom were followed during the five years of the research ${ }^{17}$. According to the authors, meshes in the abdominal wall reduced recurrences (from approximately $17 \%$ to $12 \%$ of cases), but increased serious complications (from $0.8 \%$ to $5 \%$ ) and also the cost of materials and instruments (meshes, clips, staplers, etc.). Although recurrences stabilized at lower rates, some problems with the prostheses were cumulative and their severity required a new surgical intervention. Thus, the alleged benefits of "radical or permanent cure" of these hernias were offset by such predicaments, also implying the waste of material resources, energy, and time.

Table 1 - Number of CD133+ cells per microscopic field in human incisional HS samples. Cases number 1, 5, 8, 11, and 15 expressed null values and case 6 had the highest count (58 cells).

\begin{tabular}{|c|c|c|c|c|c|c|c|c|c|c|c|c|}
\hline \multirow{2}{*}{ Patients } & \multicolumn{10}{|c|}{ Cells/microscopic field } & \multirow{2}{*}{ Total } & \multirow{2}{*}{ Average } \\
\hline & 1 & 2 & 3 & 4 & 5 & 6 & 7 & 8 & 9 & 10 & & \\
\hline 1 & 0 & 0 & 0 & 0 & 0 & 0 & 0 & 0 & 0 & 0 & 0 & 0 \\
\hline 2 & 1 & 8 & 1 & 8 & 6 & 1 & 1 & 3 & 5 & 7 & 41 & 4.1 \\
\hline 3 & 1 & 4 & 3 & 2 & 2 & 1 & 0 & 2 & 1 & 3 & 19 & 1.9 \\
\hline 4 & 6 & 2 & 4 & 1 & 2 & 2 & 1 & 0 & 2 & 1 & 21 & 2.1 \\
\hline 5 & 0 & 0 & 0 & 0 & 0 & 0 & 0 & 0 & 0 & 0 & 0 & 0 \\
\hline 6 & 13 & 5 & 8 & 6 & 3 & 2 & 5 & 8 & 6 & 2 & 58 & 5.8 \\
\hline 7 & 3 & 2 & 1 & 0 & 1 & 0 & 0 & 2 & 1 & 0 & 10 & 1 \\
\hline 8 & 0 & 0 & 0 & 0 & 0 & 0 & 0 & 0 & 0 & 0 & 0 & 0 \\
\hline 9 & 4 & 3 & 5 & 2 & 6 & 5 & 2 & 5 & 4 & 1 & 37 & 3.7 \\
\hline 10 & 2 & 1 & 0 & 1 & 0 & 0 & 0 & 2 & 1 & 0 & 7 & 0.7 \\
\hline 11 & 0 & 0 & 0 & 0 & 0 & 0 & 0 & 0 & 0 & 0 & 0 & 0 \\
\hline 12 & 2 & 3 & 3 & 1 & 0 & 2 & 1 & 0 & 1 & 2 & 15 & 1.5 \\
\hline 13 & 2 & 3 & 2 & 1 & 2 & 1 & 0 & 3 & 2 & 1 & 17 & 1.7 \\
\hline 14 & 2 & 2 & 1 & 3 & 5 & 2 & 1 & 3 & 0 & 1 & 19 & 1.9 \\
\hline 15 & 0 & 0 & 0 & 0 & 0 & 0 & 0 & 0 & 0 & 0 & 0 & 0 \\
\hline
\end{tabular}

Hernial recurrence can be identified with a high degree of reliability by the patient ${ }^{18}$, or detected by clinical examination, mainly with dynamic ultrasound, considered the gold standard for diagnosis ${ }^{19}$. However, the number of reoperations due to recurrence does not necessarily reflect the real incidence of this complication. Only patients for whom relapse affects quality of life will seek medical attention (occurrence records). Among these, some will be operated on again (treatment records), a subset four to five times smaller than those affected, because most are asymptomatic or do not want to undergo another procedure $^{20}$.

These facts suggest that herniorraphies (pure tissue repairs) that restore the anatomy of the abdominal wall will always be welcome. Hernial Sac Transposition is one of these. This 50-year-old procedure is based on wide relaxing, bilateral, and alternating incisions in the sheath of the rectus muscles, and on the use of the excess tissue represented by the longitudinally divided HS. In the synthesis, three layers of parallel, multiplanar suture are performed, involving the edges of the HS and the newly made relaxing incisions in aponeuroses. Thus, the ventral abdominal wall can be completely reconstructed, without excessive tension, either on the wall or in the abdominal cavity $^{12,21}$.

Recently, HST was recovered by a group of 
Scottish surgeons, who developed a "Peritoneal Flap Hernioplasty" based on the Da Silva technique. Instead of medializing again the rectus muscles, they placed a retromuscular mesh, which is also covered by HS flaps ${ }^{22}$. Another recent study from Romania showed very good results with this same technique ${ }^{23}$. Three decades ago, two authors drew attention to the "sandwich technique", in which the mesh is wrapped by the HS to cover parietal defects that could not be closed 24,25 . Surprisingly, no one emphasizes that HST alone provides favorable results without necessarily using a mesh as reinforcement. The skin itself is used by plastic surgeons in musculoaponeurotic repairs, since the tensile strength is greater than that of currently available allogeneic prostheses ${ }^{26}$.

Even if the defect is properly closed and a new aponeurotic linea alba is created, regardless of the procedure, it is essential to guarantee stable long-term results. Although individual genetic variations occur, providing the largest possible number of fibroblasts to each patient is not only a biologically imperative, but also of paramount importance. Pure tissue repair is an unprecedented tool for the surgeon.

The HS can certainly also be a source of these less differentiated cells, through the peritoneal layer and the abundant connective tissue that supports it. If such cells really are multipotent stem cells, this must be elucidated in other studies specifically conducted to confirm this hypothesis, including the culture of cells in selective media for strains differentiation.

Considering this characteristic, the intrinsic thickness and corresponding tensile strength seem less crucial if the mesothelium is effectively converted into a pool of matrix-producing cells, with collagen, elastic fibers, and a ground substance for the complete cure of these conditions. In addition, the HS is a well-vascularized structure, which maintains the supply of oxygen, of various cell types and raw materials, as well as a pathway of eliminating carbon dioxide and other metabolic waste. Likewise, these blood vessels maintain its adequate hydration and temperature.

In this study, five of the 15 samples examined did not show CD133+ cells, probably due to limitations in harvesting, since it was not possible to remove a large amount of the HS or the surrounding tissues. As it is an essential element in repair, it must be preserved to the maximum.

The question of whether the HS is richer in CD133+ cells than other tissues cannot be confirmed without comparative studies. It is also necessary to show whether the higher density or the simple presence of these cells can affect the quality of the scar, the final resistance, and the repair's longevity. To date, we have not found any reference that shows this association involving incisional HS. We also did not verify whether CD133 positive patients had less relapses than negative ones. This finding probably did not influence results, since all patients in our clinical trial were treated using the same technique, that is, HST.

Moreover, it is possible that these cells are not widely or evenly distributed in the HS, and that the fragments obtained have not reached places where they would be more concentrated. Immunohistochemical assays reflect the cells' ability to express this reaction after binding to the antigen-antibody complex, the intensity of which may vary according to the metabolic state and the stage of the reaction during processing. This variability is expected in any biological assay, which does not invalidate the fact that most of the studied samples expressed positive results.

The primary outcome of this investigation would be to explain the possible origin of smooth muscle cells and osteoid matrix found in some HS, based on the epithelialto-mesenchymal transition mechanism. In addition, the promising results obtained by pure tissue repairs, such as HST, could also be explained by the presence of cells that express CD133+. These undifferentiated elements can become a pool of new fibroblasts induced by reverse metaplasia. The HS is most likely an autologous, living, and biologically active prosthesis. Behind this technique, there is the belief or conviction that there must be some way to improve wound healing, not just by inducing a chronic inflammatory state through a synthetic mesh.

Once the abdominal wall architecture has been restored and consolidated by the most extensive recruitment and with the best possible performance of activated fibroblasts, it will be ready to proportionally restore its functions. Consequently, these patients will be able to recover the quality of life impaired by the hernia.

Taking advantage of the patient's own structures, including the HS, in the effort to reconstruct 
the damaged abdominal wall, renews the debate about pure tissue repairs, perhaps now more biologically based. In addition, we must always be prepared to deal with new recurrences of the disease and to offer alternative strategies, such as alloplastic prosthetic repairs. From a realistic perspective, no surgeon will perform "the last" repair, but perhaps will do it "lastly" ...

Although the scope of this study was only for screening, the HS is a presumed source of stem cells. Therefore, it may be useful in repairing incisional hernias, and not only because of its intrinsic tensile strengh. Being inherent in the hernia process, the HS will always be available, exuberant, ready to be used, and, best of all, at zero cost!

Acknowledgment: we thank the collaboration of Prof. Dr. Eneida Franco Vêncio, from the Laboratory of Biology and Molecular Pathology, Faculty of Dentistry, Federal University of Goiás, in the immunohistochemical processing stage.

Funding source: project financed by the Research Support Foundation of the State of Goiás, process no. 201210267001141 , public call 005/2012.

\title{
R E S U M O
}

\begin{abstract}
Objetivo: o saco herniário é tipicamente uma estrutura de duas camadas, constituída de tecido conjuntivo revestido por peritônio. Alguns achados incidentais, como células musculares lisas e ossificação heterotópica, podem ser explicados como o estágio final de metaplasia das células indiferenciadas que habitam o saco herniário. Este estudo teve como objetivo procurar células-tronco adultas no saco herniário incisional por um teste de triagem imuno-histoquímica. Métodos: quinze espécimes foram submetidos à análise histoquímica utilizando anticorpos monoclonais CD133, um marcador específico de células-tronco mesenquimais. As biópsias foram obtidas de pacientes submetidos ao reparo cirúrgico de hérnias incisionais, segundo a técnica da transposição com o saco herniário, proposta por Lázaro da Silva em 1971. Resultados: dois terços das amostras expressaram em média 20 (vinte) células CD133+ cada uma. Conclusão: apesar da natureza apenas de triagem deste estudo, o saco herniário pode ser considerado uma fonte de célulastronco em potencial. Isso poderia explicar aqueles achados anormais e talvez a indução de novos fibroblastos em procedimentos que o utilizam para otimizar a cicatrização dessas feridas.
\end{abstract}

Palavras chave: Células-Tronco. Peritônio. Procedimentos Cirúrgicos Operatórios. Parede Abdominal.

\section{REFERENCES}

1. Gotloib L, Gotloib LC, Khrizman V. The use of peritoneal mesothelium as a potential source of adult stem cells. Int J Artif Organs. 2007;30(6):50112.

2. Petter-Puchner AH, Fortelny RH, Gruber-Blum S, Redl $H$, Dietz $U$. The future of stem cell therapy in hernia and abdominal wall repair. Hernia. 2015;19(1):2531.

3. Barbosa CA, Amaral VF, Lázaro da Silva A. Histologia dos sacos herniários das hérnias inguinais indiretas, diretas, recidivadas e encarceradas em adultos e crianças: identificação de fibras musculares lisas. Rev Col Bras Cir. 2002;29(1):1-6.

4. Melo RM, Mendonça ET, Mendonça EQ, Mendonça MQ. Ossificação heterotópica em saco herniário incisional. Rev Col Bras Cir. 2012;39(2):151-4.

5. Aroeira LS, Aguilera A, Sanchez-Tomero JA, Bajo $M A$, del Peso $G$, Jimenez-Heffernan JA, et al. Epithelial-to-mesenchymal transition and peritoneal membrane failure in peritoneal dialysis patients: pathologic significance and potential therapeutic interventions. J Am Soc Nephrol. 2007;18(7):200413.

6. Matapurkar BG, Bhargave A, Dawson L, Sonal B. Regeneration of abdominal wall aponeurosis: new dimension in Marlex-peritoneal sandwich repair of incisional hernia. World J Surg. 1999;23(5):446-50; discussion 451.

7. Lázaro da Silva A. Surgical correction of longitudinal median or paramedian incisional hernia. Surg Gynecol Obstet.1979;148(4):579-83.

8. Melo RM. Reconstruindo a parede abdominal: o advento de uma técnica. Rev Col Bras Cir. 2010;37(6):450-6.

9. Hope PG, Carter SS, Kilby JO. The da Silva method of incisional hernia repair. Br J Surg. 1985;72(7):56970.

10. Lázaro da Silva A, Petroianu A. Incisional hernias: factors influencing development. South Med J. 1991;84(12):1500,1504.

11. Benoit L, Arnal E, Goudet P, Cougard P. [Repair of midline incisional hernias using the Lázaro 
da Silva aponeuroplasty technique]. Ann Chir. 2000;125(9):850-5. French.

12. Losanoff JE, Jones JW, Richman BW. "Separation of parts" technique: is it the only alternative for autologous repair of challenging abdominal wall defects? Am J Surg. 2002;183(5):601-2.

13. Lázaro da Silva A. Recidiva da hérnia incisional após o tratamento pela trasposição peritônio-aponeurótica longitudinal bilateral. Arq Gastroenterol. 2004;41(2):134-6.

14. de Vries Reilingh TS, Bodegom ME, van Goor $H$, Hartman EHM, van der Wilt GJ, Bleichrodt RP. Br J Surg 2007;94:791-803.

15. Flum DR, Horvath K, Koepsell T. Have outcomes of incisional hernia repair improved with time? A population-based analysis. Ann Surg. 2003;237(1):129-35

16. Klinge $U$, Krones CJ. Can we be sure that the meshes do improve the recurrence reates? Hernia. 2005;9(1):1-2.

17. Kokotovic D, Bisgaard T, Helgstrand F. Long-term recurrence and complications associated with elective incisional hernia repair. JAMA. 2016;316(15):157582.

18. Baucom RB, Ousley J, Feurer ID, Beveridge GB, Pierce RA, Holzman MD, et al. Patient reported outcomes after incisional hernia repair - establishing the ventral hernia recurrence inventory. Am J Surg. 2016;212(1):81-8.

19. Beck WC, Holzman MD, Sharp KW, Nealon WH, Dupont WD, Poulose BK. Comparative effectiveness of Dynamic Abdominal Sonography for Hernia vs Computed Tomography in the diagnosis of incisional hernia. J Am Coll Surg. 2013;216(3):447-53.

20. Helgstrand F, Rosenberg J, Kehlet $H$, Strandfelt $P$, Bisgaard T. Reoperation versus clinical recurrence rate after ventral hernia repair. Ann Surg. 2012;256(6):955-8.

21. Melo RM. El cincuentenario de la «transposición con el saco herniario» de Lázaro da Silva para reconstrucción de la pared abdominal ventral. Rev Hispanoam Hernia. 2018;6(3):156-62.

22. Malik A, Macdonald ADH, de Beaux AC, Tulloh BR. The peritoneal flap hernioplasty for repair of large ventral and incisional hernias. Hernia. 2014;18(1):3945.

23. Bara Jr. T, Gurzu S, Borz C, Muresan M, Jung I, Fulop Z, et al. Retromuscular mesh and hernial sac technique in the reconstruction of 139 cases of large median incisional hernias: one institution's experience. Hernia. 2020;24(1):99-105.

24. Matapurkar BG, Gupta AK, Agarwal AK. A new technique of "Marlex®-peritoneal sandwich in the repair of incisional hernias. World J Surg. 1991;15(6):768-70.

25. Guarnieri A. A new technique of "Marlex peritoneal sandwich" in the repair of large incisional hernias [letter]. World J Surg. 1993;17(5):683.

26. Barreiro G, Lima VS, Cavazzola LT. Abdominal skin tensile strength in aesthetic and massive weight loss patients and its role in ventral hernia repair. BMC Surg. 2019;19(1):68.
Received in: 27/05/2020

Accepted for publication:17/08/2020

Conflict of interest: no.

Funding source: yes.
Mailing address:

Renato Miranda de Melo

E-mail:dr.renatomelo@gmail.com

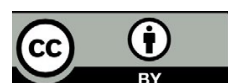

